\title{
PROPERTIES OF DRINKING YOGHURT USING DIFFERENT TYPES OF STABILIZERS
}

\author{
Sobhay, A.TH., Awad R.A., Hassan Z.M.R and El-Batawy O.I. \\ Food Sci. Dept., Fac. of Agric., Ain Shams Univ., P.O. Box 68 Hadyek Shoubra 11241, \\ Cairo, Egypt \\ *Corresponding author: Ahmedsarwat14@yahoo.com
}

Received 20 February, 2019, Accepted 9 March, 2019

\section{ABSTRACT}

Different types of drinking yoghurts were made with different types and concentrations of stabilizers. 6 treatments were made (T1, T2, T3, T4, T5 and T6) using $0.2 \%$ and $0.4 \%$ of different types stabilizers ( pectin, guar gum, and mixture (1:1) of both pectin and guar gum) for production of other yoghurt drink treatments beside the control without any stabilizers. All treatments were stored up to 14 days at $5 \pm 1^{\circ} \mathrm{C}$. Drinking yoghurt samples were evaluated for chemical, reholigical, microbiological and sensory attributes. No significant differences were observed in chemical and microbiological properties among control and treated samples. All drinking yoghurt contained levels of $\left(10^{6}-10^{7} \mathrm{cfu} / \mathrm{g}\right)$ lactic acid bacteria at the end of the refrigerated storage. Addition of stablizers showed significant differences in viscocitey and serum separation of final product. The effect was more obvious with using $0.2 \%$ stabilizer mixture $(0.1 \%$ guar gum + $0.1 \%$ High Methoxy Pectin) than other all treatments. The drinking yoghurt containing $0.2 \% \mathrm{mix}$ stabilizers $(0.1 \%$ guar gum $+0.1 \%$ High Methoxy Pectin) ranked higher sensory scores than other treatments. The best drinking yoghurt that containing $50 \%$ yoghurt, $8 \%$ sugar and $42 \%$ water should be fortified with $0.2 \%$ mix stabilizers $(0.1 \%$ guar gum $+0.1 \%$ High Methoxy Pectin)

Key words: Drinking yoghurt; High Methoxy Pectin (HMP); Guar Gum (GG); Rheological Properties; Sensory Quality.

\section{INTRODUCTION}

Yoghurt is manufactured by the acid coagulation of milk proteins during fermentation by the help of lactic acid bacteria, as Lactobacillus delbrueckii subsp. bulgaricus and Streptococcus thermophiles, its considered one of the most popular dairy products (Gharibzahedi and Chronakis, 2018). The popularity of yoghurt is due to its sensory properties, which are consumed medley around the world, and its high nutritional value (Pereira, 2014). Yoghurt may do useful effects on metabolic health by body weight control, energy homeostasis and glycemic control, so yoghurt is considered a functional food by promoting health and preventing diseases (Panahi et al 2017).

The commercial yoghurt products are categorized into set, stirred and drinkable yoghurt, based on their physical and texture properties (Chandan and Kilara, 2013). They can also be classified as plain, fruit and flavored yoghurt based on flavor and as set yoghurt, stirred yoghurt/drinking yoghurt, smoked yoghurt, concentrated yoghurt, frozen yoghurt, yoghurt drinks and beverages based on the manufacturing methods and additives. Yoghurt drinks are a product, prepared by mixing yoghurt with milk or water with sugar, stabilizer and fruit juices. Optimum consistency and minimum syneresis are desirable characteristics for yoghurt drinks and the addition of stabilizers in yoghurt drinks can reduce the serum separation during storage (Pohjanheimo and Sandell, 2009).

Various types of stabilizers could be used in drinking yoghurt manufacture to improve the quality properties of final products. Methoxyl pectin is one of the most usually applied hydrocolloids and gelling polysaccharides in the food industry. Methoxyl pectin is classified to high methoxyl pectin (HMP), if half or more of the carboxyl gps are esterified, and low methoxyl pectin (LMP), if less than half of the carboxyl gps are esterified (Lam et al 2007). The degree of (DE) effect on pectin solubili- 
ty and its gelation properties. HMP is extensively used as an ideal stabilizer in acid drinking yoghurt because it helps in preventing flocculation of milk CSNs and improving and maintaining the preferable properties of drinking yoghurt. Syneresis which mag be preset in the package adversely affects the acceptability of the consumers. Calcium ions help HMP to interact casein and prevent their flocculation and hence syneresis by ionic and steric stabilization in drinking yoghurt. (Foley and Mulcahy, 1989) found that the production drinking yoghurt long shelf life required the addition of HMP to reducing syneresis. GG is obtained from the endosperm of cyamoposis tetragonolobus or cyamopsis psoraloides, it is one of the cheapest sources of galactomannan (Koksoy and Kilic, 2004). GG is polysaccharide obtained from the guar plant high molecular weight, odourless and white to yellowish white appearance (Thombare et al 2016).

$\mathrm{GG}$ is water soluble. In water surroundings, galactose units which present on mannose units interact $\mathrm{H}_{2} \mathrm{O}$ molecules and make inter- molecular chain entanglement which increase thickening and viscosity of the solution. GG when dispersed in hot and cold $\mathrm{H}_{2} \mathrm{O}$, results in viscous colloidal solution. GG can achieve its full viscosity in cold $\mathrm{H}_{2} \mathrm{O}$, while other gums need prolonged heating to acquire the same viscosity. The most influencing variables temperature, concentration, $\mathrm{pH}$, presence and dispersion of foreign substances are responsible for affecting the rate and the viscosity of GG, (Pathania et al 2016). GG was used in sweetened yoghurt products, (Oliviera et al 2002). Therefore, (Azarikia and Abbasi, 2010) the use of GG is recommended in cultured milk products because heat treatment isn't applied in their production. The objectives of this study were to improve the texture and quality Properties of drinking yoghurt. by adding different types and concentrations of stabilizers.

\section{MATERIALS AND METHODS}

\section{Materials}

\section{A. Ingredients}

Fresh cow's milk was obtained from the herd of the dairy cattle at Faculty of Agriculture, Cairo University, Giza, Egypt. Skimmed milk powder (grade medium heat) produced by AGRI, BEST, Holland was obtained from the local market. Sugar (Sucrose) Commercial grade granulated cane sugar (Sucrose) produced by the sugar and Integrated Industries Co. at Hawamdia, Egypt for used. Guar
Gum powder (Food grade- Mesh: 200, Viscosity : 5000-5500 CPS) was obtained from Rajasthan, India. High Methoxyi Pectin (HMP) APA102 ( Yantai Andre Pectin Co.Ltd-889 XinchengStreet- Muping Economic Development Zone Yantai, P.C. 264100 obtained from China.

Table 1. Some chemical properties of different ingredients used for making the various treatments of drinking yoghurt.

\begin{tabular}{|c|c|c|c|c|c|c|}
\hline Ingredients & $\begin{array}{c}\text { Moisture } \\
\%\end{array}$ & $\begin{array}{c}\text { Ash } \\
\%\end{array}$ & $\begin{array}{c}\text { Fat } \\
\%\end{array}$ & $\begin{array}{c}\text { Total } \\
\text { protein } \\
\%\end{array}$ & $\begin{array}{c}\text { Acidity } \\
\%\end{array}$ & $\begin{array}{c}\mathbf{p H} \\
\text { Value }\end{array}$ \\
\hline $\begin{array}{c}\text { Fresh Cow's } \\
\text { milk }\end{array}$ & 88.35 & 0.73 & 3.10 & 3.20 & 0.17 & 6.60 \\
SMP & 3.83 & 6.44 & 0.44 & 32.29 & 1.11 & 6.55 \\
HM Pectin & 6.11 & 0.06 & $\mathrm{ND}$ & $\mathrm{ND}$ & $\mathrm{ND}$ & 3.30 \\
Guar Gum & 10.27 & 0.65 & $\mathrm{ND}$ & 4.70 & $\mathrm{ND}$ & 6.20 \\
Sugar & 0.07 & 0.0 & $\mathrm{ND}$ & $\mathrm{ND}$ & 0.17 & 5.84 \\
\hline
\end{tabular}

ND: not determined.

SMP: Skimmed milk powder

HM Pectin: High Methoxyi Pectin

\section{B. Starter cultures}

Yoghurt starter culture (YC-X11 DIP 50u) contains Streptococcus thermophilus and Lactobacillus delbrueckii subsp. bulgaricus was obtained from Chr. Hansens Laboratiers, Denmark and activated at $42^{\circ} \mathrm{C}$ using $12 \%$ sterilized reconstituted skimmed milk. After incubation at $42^{\circ} \mathrm{C}$ for $4-5 \mathrm{~h}$, the activated culture was freshly used.

\section{Experiment of procedures}

\section{A. Preparation the mix of water, sugar and sta-} bilizer

High methoxy pectin (HMP) and guar gum (GG) stabilizers were used in preparation of different drinking yoghurt mixes. Sucrose solution was prepared at $8 \%$ concentrate. The solution was divided into seven portions, the first portion without stabilizers used for making control drinking yoghurt. Other portions were fortified with $0.2 \%$ and $0.4 \%$ of pectin, or guar gum, or mixture of HMP and GG (1:1) and used for production of drinking yoghurt treatments T1, T2, T3, T4, T5 and T6, respectively. All mixes were heated to $90{ }^{\circ} \mathrm{C}$ for 10 min and then rapidly cooled to room temperature and then stored in refrigerator $\left(5 \pm 1^{\circ} \mathrm{C}\right)$ till used. 


\section{B. Production of drinking yoghurt}

Different treatments of drinking yoghurt were made according to the procedure of (Farahat and El-Batawy, 2013) with some modifications as follows: Cow's milk (fat $3 \%$, protein $3.20 \%$, total solids $12.3 \%$ and acidity $0.17 \%$ ) was used for yoghurt production and $2 \%$ skimmed milk powder was added to increase solids of milk. The mix was heat treated to $85^{\circ} \mathrm{C}$ for $10 \mathrm{~min}$. and then rapidly cooled to $45^{\circ} \mathrm{C}$. The adivated yoghurt culture was added at the rate of $2 \%(\mathrm{w} / \mathrm{v})$. The inoculated mix was filled into $2.0 \mathrm{~kg}$ plastic contrives and incubated at $42.0 \pm 5^{\circ} \mathrm{C}$. till the $\mathrm{pH}$ reach 4.60 . At this point, the yoghurt was stored in a refrigerator $\left(5 \pm 1^{\circ} \mathrm{C}\right)$ overnight. Different yoghurt drinks were prepared by adding $50 \%$ yoghurt and $50 \%$ different mixes of water, sugar and stabilizers. [C: Control drinking yoghurt $(50 \%$ Yoghurt $+8 \%$ Sugar $+42 \%$ Water, T1: drinking yoghurt made with $50 \%$ Yoghurt $+8 \%$ Sugar $+0.2 \%$ HMP $+42 \%$ Water, T2: drinking yoghurt made with $50 \%$ Yoghurt $+8 \%$ Sugar + $0.4 \%$ HM Pectin $+42 \%$ Water, T3: drinking yoghurt made with $50 \%$ Yoghurt $+8 \%$ Sugar $+0.2 \%$ Guar gum $+42 \%$ Water, T4: drinking yoghurt made with $50 \%$ Yoghurt $+8 \%$ Sugar $+0.4 \%$ Guar gum $+42 \%$ Water, T5: drinking yoghurt made with $50 \%$ Yoghurt $+8 \%$ Sugar $+0.1 \%$ HMP $+0.1 \%$ Guar gum $+42 \%$ Water and T6: drinking yoghurt made with $50 \%$ Yoghurt $+8 \%$ Sugar $+0.2 \%$ HMP $+0.2 \%$ Guar gum $+42 \%$ Water]. The drinking yoghurt mixes were stirred and filled into $250 \mathrm{~g}$ plastic cups. Three replicates were done for each treatment. The resultant drinking yoghurt samples were stored in refrigerator $\left(5 \pm 1^{\circ} \mathrm{C}\right)$ for 14 days. The samples were analyzed at 1, 7 and 14 days intervals of the cooled storage.

\section{Analytical methods}

Protein, fat, total solid and ash contents of drinking yoghurt samples were determined according to (AOAC, 2012). Titratable acidity as lactic acid (TA \%) was determined as given by (Ling, 1963). The $\mathrm{pH}$ value was measured in all samples of drinking yoghurt using lad $\mathrm{pH}$-meter with a glass electrode (Hanna model 8417 digital pH meter).

The viscosity was measured using a digital rotary viscometer (Model NDJ-9S) with a spindle No. 3 at $30 \mathrm{rpm}$ for 40 seconds and the temperature of $20^{\circ} \mathrm{C}$. The test was replicated three times according to (Ibarz and Barbosa-Canovas, 2002).

The serum separation of drinking yogurt was measured by the method of (Koksoy and Kilic, 2003).
Lactobacilli count was determined using MRS agar medium according to (De Man et al 1960). Str. thermophilus was counted using M17 agar medium (Terzaghi and Sandine, 1975). Coliform count was enumerated using Violet Red Bile Agar medium as reported by American Public Health Association, 1994). Yeasts and moulds were counted on Malt-Extract Agar medium as suggested by (Harrigan and McCance, 1966).

Scoring properties of drinking yoghurt was done by ten stuff members at Food Sci. Dep., Fac. of Agric., Ain Shams Univ., Samples were estimated for: appearance (10 points), consistency (40 points) and flavour (50 points) according to the scheme of (Keating and Randwhite, 1990).

The obtained data were exposed to analysis of variance. Duncan's multiple range test at $5 \%$ level of significance was used to compare between means. The analysis was carried out using the PROC ANOVA procedure of Statistical Analysis System (SAS, 2006).

\section{RESULTS AND DISCUSSION}

\section{Physochemical properties}

Table (2) presents some physochemical properties of drinking yoghurt fortified with different types and ratios of stabilizers during storage at $5 \pm 1^{\circ} \mathrm{C}$ for 14 days. The data showed that the types and concentrations of different stabilizers added to different drinking yoghurt treatments had no significant effect on total solid, fat, total protein, ash titratable acidity contents and $\mathrm{pH}$ value in all final products. This could be due to the very low quantity of different stabilizers ( 0.2 and $0.4 \%)$ added to various drinking yoghurt treatments and these low quantity had no effect on total chemical composition of final product. The obtained results agree with (Hematyar et al 2012) who found that, using xanthan and carrageenan at different concentrations had no effect on chemical composition and $\mathrm{pH}$ value of yoghurt.

Dry matter content was slightly increased in all drinking yoghurt because the refrigated storage period improved (CSP) up to 14 days. High refrigerated storage period may be due to evaporation of some water during the CSP as previously described ascribed by (El-Nagar and Shenana, 1998). Total nitrogen and ash were high nitrogen and ash content in all drinking yoghurt treatments were due to the refrigerated storage period improved up to 14 days. Changes in dry matter content during storage may dues these differences. 
Table 2. Gross Chemical composition $\mathrm{pH}$ and acidity of drinking yoghurt fortified with different types and concentrations of stabilizers along the storage at $5 \pm 1^{\circ} \mathrm{C}$ for 14 days.

\begin{tabular}{|c|c|c|c|c|c|c|}
\hline \multicolumn{7}{|c|}{1 Day } \\
\hline Sample & $\begin{array}{l}\text { TS } \\
(\%)\end{array}$ & $\begin{array}{l}\text { Fat } \\
(\%)\end{array}$ & $\begin{array}{c}\text { Total } \\
\text { protein } \\
(\%)\end{array}$ & $\begin{array}{l}\text { Ash } \\
\text { (\%) }\end{array}$ & $\begin{array}{c}\text { pH } \\
\text { Value }\end{array}$ & $\begin{array}{c}\text { Acidity } \\
(\%)\end{array}$ \\
\hline C & $13.55^{\mathrm{Ac}}$ & $1.48^{\mathrm{Ac}}$ & $1.97^{\mathrm{Ac}}$ & $0.46^{\mathrm{Ac}}$ & $4.01^{\mathrm{Ac}}$ & $0.47^{\mathrm{Ac}}$ \\
\hline T1 & $13.91^{\mathrm{Ac}}$ & $1.46^{\mathrm{Ac}}$ & $2.00^{\mathrm{Ac}}$ & $0.44^{\mathrm{Ac}}$ & $4.02^{\mathrm{Ac}}$ & $0.48^{A c}$ \\
\hline T2 & $13.49^{A C}$ & $1.48^{\mathrm{Ac}}$ & $2.03^{A c}$ & $0.48^{A c}$ & $4.09^{\mathrm{Ac}}$ & $0.45^{\mathrm{Ac}}$ \\
\hline T3 & $13.38^{A c}$ & $1.45^{\mathrm{Ac}}$ & $2.05^{\mathrm{Ac}}$ & $0.50^{\mathrm{Ac}}$ & $4.22^{\mathrm{Ac}}$ & $0.43^{A c}$ \\
\hline T4 & $13.67^{A c}$ & $1.41^{\mathrm{Ac}}$ & $1.98^{\mathrm{Ac}}$ & $0.43^{A c}$ & $4.08^{A c}$ & $0.47^{A c}$ \\
\hline T5 & $13.53^{\mathrm{Ac}}$ & $1.39^{A c}$ & $2.05^{\mathrm{Ac}}$ & $0.44^{\mathrm{Ac}}$ & $4.35^{\mathrm{Ac}}$ & $0.48^{\mathrm{Ac}}$ \\
\hline T6 & $14.21^{\mathrm{Ac}}$ & $1.47^{\mathrm{Ac}}$ & $2.07^{\mathrm{Ac}}$ & $0.42^{\mathrm{Ac}}$ & $4.13^{\mathrm{Ac}}$ & $0.44^{\mathrm{Ac}}$ \\
\hline \multicolumn{7}{|c|}{7 Day } \\
\hline C & $13.70^{\mathrm{Ab}}$ & $1.50^{\mathrm{Ab}}$ & $1.97^{\mathrm{Ab}}$ & $0.48^{\mathrm{Ab}}$ & $3.99^{\mathrm{Ab}}$ & $0.48^{\mathrm{Ab}}$ \\
\hline T1 & $13.92^{\mathrm{Ab}}$ & $1.47^{\mathrm{Ab}}$ & $2.01^{\mathrm{Ab}}$ & $0.47^{\mathrm{Ab}}$ & $3.99^{\mathrm{Ab}}$ & $0.48^{A b}$ \\
\hline T2 & $13.55^{A b}$ & $1.48^{\mathrm{Ab}}$ & $2.04^{A b}$ & $0.52^{A b}$ & $4.05^{\mathrm{Ab}}$ & $0.43^{\mathrm{Ab}}$ \\
\hline T3 & $13.43^{\mathrm{Ab}}$ & $1.46^{\mathrm{Ab}}$ & $2.06^{\mathrm{Ab}}$ & $0.53^{\mathrm{Ab}}$ & $3.98^{\mathrm{Ab}}$ & $0.48^{\mathrm{Ab}}$ \\
\hline T4 & $13.81^{\mathrm{Ab}}$ & $1.42^{\mathrm{Ab}}$ & $1.98^{\mathrm{Ab}}$ & $0.50^{\mathrm{Ab}}$ & $3.97^{\mathrm{Ab}}$ & $0.48^{A b}$ \\
\hline T5 & $13.66^{\mathrm{Ab}}$ & $1.40^{\mathrm{Ab}}$ & $2.06^{\mathrm{Ab}}$ & $0.47^{\mathrm{Ab}}$ & $3.92^{\mathrm{Ab}}$ & $0.48^{\mathrm{Ab}}$ \\
\hline T6 & $14.25^{\mathrm{Ab}}$ & $1.47^{\mathrm{Ab}}$ & $2.08^{\mathrm{Ab}}$ & $0.46^{\mathrm{Ab}}$ & $3.96^{\mathrm{Ab}}$ & $0.48^{\mathrm{Ab}}$ \\
\hline \multicolumn{7}{|c|}{14 Day } \\
\hline C & $13.83^{\mathrm{Aa}}$ & $1.50^{\mathrm{Aa}}$ & $1.98^{\mathrm{Aa}}$ & $0.52^{\mathrm{Aa}}$ & $3.82^{\mathrm{Aa}}$ & $0.63^{\mathrm{Aa}}$ \\
\hline T1 & $13.97^{\mathrm{Aa}}$ & $1.48^{\mathrm{Aa}}$ & $2.03^{\mathrm{Aa}}$ & $0.54^{\mathrm{Aa}}$ & $3.79^{\mathrm{Aa}}$ & $0.59^{\mathrm{Aa}}$ \\
\hline T2 & $13.72^{\mathrm{Aa}}$ & $1.48^{\mathrm{Aa}}$ & $2.07^{\mathrm{Aa}}$ & $0.56^{\mathrm{Aa}}$ & $3.87^{\mathrm{Aa}}$ & $0.59^{\mathrm{Aa}}$ \\
\hline T3 & $13.50^{\mathrm{Aa}}$ & $1.47^{\mathrm{Aa}}$ & $2.07^{\mathrm{Aa}}$ & $0.53^{\mathrm{Aa}}$ & $3.80^{\mathrm{Aa}}$ & $0.53^{\mathrm{Aa}}$ \\
\hline T4 & $13.87^{\mathrm{Aa}}$ & $1.43^{\mathrm{Aa}}$ & $1.99^{\mathrm{Aa}}$ & $0.57^{\mathrm{Aa}}$ & $3.80^{\mathrm{Aa}}$ & $0.59^{A a}$ \\
\hline T5 & $13.74^{\mathrm{Aa}}$ & $1.40^{\mathrm{Aa}}$ & $2.07^{\mathrm{Aa}}$ & $0.52^{\mathrm{Aa}}$ & $3.73^{\mathrm{Aa}}$ & $0.54^{\mathrm{Aa}}$ \\
\hline T6 & $14.32^{\mathrm{Aa}}$ & $1.48^{\mathrm{Aa}}$ & $2.09^{\mathrm{Aa}}$ & $0.50^{\mathrm{Aa}}$ & $3.78^{\mathrm{Aa}}$ & $0.57^{\mathrm{Aa}}$ \\
\hline
\end{tabular}

C: Control drinking yoghurt $(50 \%$ Yoghurt $+8 \%$ Sugar $+42 \%$ Water)

T1: drinking yoghurt made with 50\% Yoghurt $+8 \%$ Sugar $+0.2 \%$ HMP + $42 \%$ Water

T2: drinking yoghurt made with $50 \%$ Yoghurt $+8 \%$ Sugar $+0.4 \%$ HM Pectin $+42 \%$ Water

T3: drinking yoghurt made with $50 \%$ Yoghurt $+8 \%$ Sugar $+0.2 \%$ Guar gum $+42 \%$ Water

T4: drinking yoghurt made with $50 \%$ Yoghurt $+8 \%$ Sugar $+0.4 \%$ Guar gum $+42 \%$ Water

T5: drinking yoghurt made with $50 \%$ Yoghurt $+8 \%$ Sugar $+0.1 \%$ HMP $+0.1 \%$ Guar gum $+42 \%$ Water

T6: drinking yoghurt made with $50 \%$ Yoghurt $+8 \%$ Sugar $+0.2 \%$ HMP $+0.2 \%$ Guar gum $+42 \%$ Water

A, B, C: Means with same letter among treatments in the same storage period are not significantly different.

$a, b, c$ : Means with same letter for same treatment during storage periods are not significantly different.

Generally, the percent titratable acidity gradually increased in all treatments and control samples during the CSP., The increased of titratable acidi- ty\% during the storage of drinking yoghurt were (Abd EL-Salam et al 1996, Mehanna et al 2003, Kebary et al 2004 and EL-Batawy, 2012).

\section{Dynamic viscosity}

Data in Table (3) refer that, using the HMP as stabilizer agent either at 0.2 or $0.4 \%$ in making of drinking yoghurt didn't effect the final product viscosity. These results agree with (Koksoy and Kilic, 2004) who stated that low level of High Methoxyi Pectin might not coat all casein particles and originate enough electrostatic and steric repulsions set the dispersion. At high level of High Methoxyi Pectin, the casein particles may by covered and also to react $\mathrm{H}_{2} \mathrm{O}$ which may be present for settling the texture of the product. On the other hand, using guar gam as stabilizer agent individual or mixed with High Methoxyi Pectin (HMP) in preparation of drinking yoghurt caused significant effect on viscosity compared with control. Drinking yoghurt fortified with $0.4 \%$ guar gum were significant higher viscosity than treatments fortified with $0.2 \%$. This increase of viscosity in the produced drinking yoghurt with guar gum as stabilizer is perhaps due to the ability of guar gum (GG) to create a weak network structure in drinking yoghurt (Pathania et al 2016). (Koksoy and Kilic, 2004) more polysaccharides at high level of $G G$ are present to coat the CSN particles and react $\mathrm{H}_{2} \mathrm{O}$ which may be present for improving viscosity of fluid. Similar results were obtained by other studies as well. (Ibrahim et al 2009) who showed that guar gum (GG) was highly surface active at the oil and $\mathrm{H}_{2} \mathrm{O}$ interface because of the galactose branch unit and polymannose backbone failed to mix $\mathrm{H}_{2} \mathrm{O}$. presence of $\mathrm{GG}$ in this hydrophobicity might raise the merit of complexes and bulk viscosity of the product. (Long et al 2012).

The apparent viscosity partially developed in all the produced drinking yoghurt because the refrigerated storage period improved up to 14 days. The excess in apparent viscosity during the storage period was perhaps due to evaporation of some $\mathrm{H}_{2} \mathrm{O}$ during the storage (EI Batawy, 2012).

\section{Serum separation}

Aggregation and sedimentation flocculation of CSN particles during storage casein syneresis in drinking yoghurt products. stabilizers must be added to inhibit syneresis in drinking yoghurt (Lucey et al 1999). As shown in Table (3). Control drinking yoghurt made without stabilizers was the highest serum separation along all treatments and allo- 
ver the storage period. Fortification the drinking yoghurt with guar gum and or HMP resulted significant decrease in serum separation value compared with control. Therefore, addition of stabilizers either guar gum or HMP in making of drinking yoghurt play an important role in reduction of syneresis in the final product. Syneresis value was significant higher in drinking yoghurt with HMP than treatments made with guar gum as stabilizer. Increasing the ratios of stabilizer added to drinking yoghurt due to decreasing the syneresis value in the final product these results agree with (Nikoofar et al 2013) who HMP must be added in high concentrations produce a weak gel network and to attain long-term stability by inhibiting CSN aggregates sedimentation. Limitation of the suspended CSN particles can be occurred during electrostatic and steric interactions (Pathania et al 2016). Also, the HMP molecules in drinking yoghurt can react with CSNs during calcium ions and inhibit their aggregation, sedimentation and so serum separation by ionic and steric settlement (Joudaki et al 2013, and Lucey et al 1999). Guar gum (GG) can be used in yoghurt to inhibit serum separation because it shows high solubility in $\mathrm{H}_{2} \mathrm{O}$. GG must be present in high concentration to decrease syneresis. $0.4 \%$ GG was found to produce a constant inter connected network which catch $\mathrm{H}_{2} \mathrm{O}$ in yoghurt (Fiszman and Salvador, 1999). The same in drinking yoghurt, GG may settled the network in duding the casein micelles and catching $\mathrm{H}_{2} \mathrm{O}$ in between. (Harwalker et al 1986, and Abd ElSalam et al 1996) Xanthan gum is controlling as a method of limiting serum separation of drinking yoghurt. Stabilizers (e.g. CMC, HMP, GG, Carrageenan) react with the charges on the surface of casein micelles to support the casein network and decrease serum separation and are classified as adsorbing polysaccharides. Neutral Stabilizers (e.g. Xanthan, GG, LBG) are classified as nonadsorbing polysaccharides, reduce serum separation is by increasing viscosity of the continuous phase. (Hansen, 1993).

The Serum separation slightly decreased in all drinking yoghurt because the refrigerated storage period improved up to 14 days. This decrease in serum separation due to at lower temperature the bonds between the particles of the gel are stronger or their numbers are greater. Perhaps, this is due to the particle are bigger and liked to each other over a bigger area (Walter et al 1993). The obtained results are agreement with (Doleyres et al 2005) yoghurt containing EPS-producing cultures showed high $\mathrm{H}_{2} \mathrm{O}$ solubility which increased during storage and thereby minimize serum separation. Also, the changes in the percent of serum separation storage period agree with that obtained by (Nikoofar et al 2013).

Table 3. Viscosity ( $\mathrm{m} \mathrm{Pa} \mathrm{s}$ ) and Serum separation $(\mathrm{mL} / 10 \mathrm{~mL})$ of drinking yoghurt made with different types and concentrations of stabilizers along the storage at $5 \pm 1^{\circ} \mathrm{C}$ for 14 days.

\begin{tabular}{|c|c|c|c|}
\hline \multicolumn{4}{|c|}{ Viscosity (m Pa s) } \\
\hline Treatment & 1 Day $^{\mathrm{C}}$ & $\mathbf{7}$ Day & 14 Day \\
\hline C & $12.20 \pm 0.70^{\mathrm{Cc}}$ & $12.80 \pm 0.80^{\mathrm{Cb}}$ & $13.90 \pm 0.90^{\mathrm{Ca}}$ \\
T1 & $13.10 \pm 0.70^{\mathrm{Cc}}$ & $14.80 \pm 0.90^{\mathrm{Cb}}$ & $15.95 \pm 0.80^{\mathrm{Ca}}$ \\
T2 & $14.00 \pm 0.80^{\mathrm{Cc}}$ & $15.20 \pm 0.90^{\mathrm{Cb}}$ & $16.00 \pm 0.90^{\mathrm{Ca}}$ \\
T3 & $27.00 \pm 1.00^{\mathrm{Bc}}$ & $28.10 \pm 1.30^{\mathrm{Bb}}$ & $28.60 \pm 1.20^{\mathrm{Ba}}$ \\
T4 & $55.60 \pm 1.30^{\mathrm{Ac}}$ & $56.40 \pm 1.40^{\mathrm{Ab}}$ & $56.60 \pm 1.30^{\mathrm{Aa}}$ \\
T5 & $19.20 \pm 0.90^{\mathrm{Bc}}$ & $22.80 \pm 1.10^{\mathrm{Bb}}$ & $22.90 \pm 1.10^{\mathrm{Ba}}$ \\
T6 & $29.50 \pm 0.90^{\mathrm{Bc}}$ & $31.20 \pm 1.20^{\mathrm{Bb}}$ & $31.90 \pm 1.20^{\mathrm{Ba}}$ \\
\hline & Serum separation $\left(\mathbf{m L} / 10^{\mathrm{mL}}\right)$ \\
\hline C & $1.33 \pm 0.16^{\mathrm{Aa}}$ & $0.77 \pm 0.22^{\mathrm{Ab}}$ & $0.58 \pm 0.21^{\mathrm{Ac}}$ \\
T1 & $0.67 \pm 0.08^{\mathrm{Ba}}$ & $0.41 \pm 0.10^{\mathrm{Bb}}$ & $0.36 \pm 0.14^{\mathrm{Bc}}$ \\
T2 & $0.36 \pm 0.77^{\mathrm{Ba}}$ & $0.22 \pm 0.17^{\mathrm{Bb}}$ & $0.19 \pm 0.66^{\mathrm{Bc}}$ \\
T3 & $0.11 \pm 0.00^{\mathrm{Ca}}$ & $0.06 \pm 0.00^{\mathrm{Cb}}$ & $0.00 \pm 0.00^{\mathrm{Cc}}$ \\
T4 & $0.08 \pm 0.03^{\mathrm{Ca}}$ & $0.04 \pm 0.00^{\mathrm{Cb}}$ & $0.00 \pm 0.00^{\mathrm{Cc}}$ \\
T5 & $0.10 \pm 0.02^{\mathrm{Ca}}$ & $0.07 \pm 0.00^{\mathrm{Cb}}$ & $0.00 \pm 0.00^{\mathrm{Cc}}$ \\
T6 & $0.08 \pm 0.06^{\mathrm{Ca}}$ & $0.05 \pm 0.00^{\mathrm{Cb}}$ & $0.00 \pm 0.00^{\mathrm{Cc}}$ \\
\hline
\end{tabular}

*See legend to Table (2) for details

\section{Microbiological examination}

As shown in Table (4), show the data of Microbiological examination of the produced drinking yoghurt. There were no significant differences in the viability of two different starter cultures (Streptococcus thrmophilus bacteria and Lactobacillus delbrueckii subsp. bulgaricus) along all treatments either fresh drinking yoghurt or during the interval cold storage till $14^{\text {th }}$ day. Therefore, it could be stated that, types and concentrations of stabilizers used in making drinking yoghurt do not affect on viability of yoghurt starter cultures along cold storage period. these results agree with (Basiri et al 2018) who found that, addition of mucilage as stabilizer to yogurt did not significantly effect on the growth and viability of starter culture in the final product along the storage period.

Streptococcus thrmophilus bacteria and Lactobacillus delbrueckii subsp. bulgaricus partially decreased during the first week of storage and then 
gradually until the end of the storage period. The bacterial were sensitive acid achieved through the cold storage period so lactic acid bacterial counts decreased gradually. The results are in harmony with those obtained by (Ibrahim et al 2004, Oliveira et al 2009, Pseephol \& Sherkat, 2009 and El-Batawy, 2012).

There were no coliform bacteria in all drinking yoghurt samples either fresh or during refrigerated storage, because of the efficient heat treatment of the different yoghurt milks ( $85^{\circ} \mathrm{C}$ for $15 \mathrm{~min}$ ) and de contamination conditions during making and storage of drinking yoghurt and the effect of acidity in different yoghurt which prevent pathogenic bacteria growth. The results are in harmony with the results of (Gould, 1991, and El Batawy, 2012).

Table 4. Microbiological examinations of drinking yoghurt made with different types and concentrations of stabilizers along the storage at $5 \pm 1^{\circ} \mathrm{C}$ for 14 days.

\begin{tabular}{|c|c|c|c|}
\hline \multicolumn{4}{|c|}{ Microbiological counts (log cfu/cm $\mathbf{~}^{\text {) }}$} \\
\hline \multicolumn{4}{|c|}{ Str. thermophilus } \\
\hline Treatment & 1 Day & 7 Day & 14 Day \\
\hline C & $7.88^{\mathrm{Aa}}$ & $7.32^{\mathrm{Ab}}$ & $6.22^{\mathrm{Ac}}$ \\
T1 & $7.87^{\mathrm{Aa}}$ & $7.23^{\mathrm{Ab}}$ & $6.15^{\mathrm{Ac}}$ \\
T2 & $7.57^{\mathrm{Aa}}$ & $7.10^{\mathrm{Ab}}$ & $5.85^{\mathrm{Ac}}$ \\
T3 & $7.85^{\mathrm{Aa}}$ & $7.25^{\mathrm{Ab}}$ & $6.35^{\mathrm{Ac}}$ \\
T4 & $7.66^{\mathrm{Aa}}$ & $7.03^{\mathrm{Ab}}$ & $6.32^{\mathrm{Ac}}$ \\
T5 & $7.89^{\mathrm{Aa}}$ & $7.01^{\mathrm{Ab}}$ & $6.04^{\mathrm{Ac}}$ \\
T6 & $7.95^{\mathrm{Aa}}$ & $6.88^{\mathrm{Ab}}$ & $6.01^{\mathrm{Ac}}$ \\
\hline \multicolumn{4}{|c|}{ Lb. delbrueckii subsp. Bulgaricus } \\
\hline C & $7.27^{\mathrm{Aa}}$ & $6.85^{\mathrm{Ab}}$ & $5.62^{\mathrm{Ac}}$ \\
T1 & $7.62^{\mathrm{Aa}}$ & $7.21^{\mathrm{Ab}}$ & $6.35^{\mathrm{Ac}}$ \\
T2 & $7.12^{\mathrm{Aa}}$ & $6.58^{\mathrm{Ab}}$ & $5.65^{\mathrm{Ac}}$ \\
T3 & $7.31^{\mathrm{Aa}}$ & $6.86^{\mathrm{Ab}}$ & $5.74^{\mathrm{Ac}}$ \\
T4 & $7.32^{\mathrm{Aa}}$ & $6.87^{\mathrm{Ab}}$ & $6.03^{\mathrm{Ac}}$ \\
T5 & $7.32^{\mathrm{Aa}}$ & $6.31^{\mathrm{Ab}}$ & $5.98^{\mathrm{Ac}}$ \\
T6 & $7.41^{\mathrm{Aa}}$ & $6.98^{\mathrm{Ab}}$ & $6.06^{\mathrm{Ac}}$ \\
\hline
\end{tabular}

see legend to Table (2) for details

All drinking yoghurt samples were free from yeast and mold till $7^{\text {th }}$ day of storage period. At $14^{\text {th }}$ day from storage period, yeast and mould has been appeared but were less than $10 \mathrm{cfu} / \mathrm{ml}$ and this may be due to some looking in the bottles lead. The obtained results in agreement with (EI Batawy, 2012).

Generally, using different types of stabilizers (HMP, guar gum or mixture (1:1) of both) at different concentrations $(0.2,0.4 \%)$ in drinking yoghurt making had no significant effect on the microbio- logical quality of the final product when fresh or along cold storage period.

\section{Sensory properties}

Data of Table (5), cleav the Sensory properties of the produced drinking yoghurt when fresh and during the storage. there were significant differeces in appearance scores between the control and all different drinking yoghurt treatments. On the other hand, there were significant differeces in consistency scores between the control and all different drinking yoghurt treatments. This proves that, the presence of types and concentrations of different stabilizers of drinking yoghurt added plays a significant role in enhancing the consistency of drinking yoghurt products. This could be due to the HMP and GG molecules in drinking yoghurt can react with CSNs through calcium ions and inhibit their aggregation, sedimentation and so syneresis by ionic and steric stabilization (Joudaki et al 2013, and Lucey et al 1999). Also, (Penna et al 2001) high consistency coefficient improve the sensory properties of lactic beverages.

Dut to the flavour scors, there were no significant differeces in Flavor scores between the control and all different drinking yoghurt treatments. These findings are in agreement with the rescults reported by (Joudaki et al 2013) was that made with who HMP levels up to $0.8 \%$ had no affect on the taste and the odor of long life drinking yoghurt. Also, (Guven, 1998) HMP at $0.5 \%$ concentration increased the viscosity without affecting the taste and the odor of yoghurt.

Total results were partially reduced during the first 7 days of refrigaled stoage period then reduced gradually until the end of the storage period (14 days). This reduction may be to development of acid which effect on the rheological and sensory properties. The shelf life of drinking yoghurt couldn't be increased for more than 14 days of storage at $4^{\circ} \mathrm{C}$, because of the decrease in the total scors of organoleptic properties of all different drinking yoghurt treatments were dropped. These findings are in agreement with rescults reported by (Ebrahimi et al 2015, and Farahat and El-Batawy, 2013).

In general, all the produced drinking yoghurt were acceptabe and the best produced $50 \%$ yoghurt culture + $8 \%$ sugare + mix stabilizers $0.1 \%$ guar gum (GG) $+0.1 \%$ High Methoxy Pectin (HMP). 
Table 5. Sensory evaluation of drinking yoghurt made with different types and concentrations of stabilizers along the storage at $5 \pm 1^{\circ} \mathrm{C}$ for 14 days.

\begin{tabular}{|c|c|c|c|c|}
\hline \multicolumn{5}{|c|}{ Sensory evaluation } \\
\hline \multirow{2}{*}{ Criteria } & \multirow{2}{*}{ Treatment } & \multicolumn{3}{|c|}{ Storage period (day) } \\
\hline & & 1 & 7 & 14 \\
\hline \multirow{2}{*}{ 을 } & C & $7.00^{\mathrm{Ba}}$ & $6.00^{\mathrm{Bb}}$ & $5.50^{\mathrm{Bc}}$ \\
\hline & T1 & $8.00^{\mathrm{Aa}}$ & $7.00^{\mathrm{Ab}}$ & $6.00^{A c}$ \\
\hline \multirow{5}{*}{ 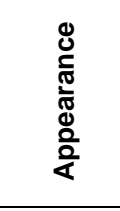 } & T2 & $8.00^{\mathrm{Aa}}$ & $7.00^{\mathrm{Ab}}$ & $6.50^{\mathrm{Ac}}$ \\
\hline & T3 & $8.00^{\mathrm{Aa}}$ & $7.50^{\mathrm{Ab}}$ & $6.50^{\mathrm{Ac}}$ \\
\hline & T4 & $8.00^{\mathrm{Aa}}$ & $7.50^{\mathrm{Ab}}$ & $6.50^{\mathrm{Ac}}$ \\
\hline & T5 & $8.00^{\mathrm{Aa}}$ & $7.50^{\mathrm{Ab}}$ & $6.00^{\mathrm{Ac}}$ \\
\hline & T6 & $8.00^{\mathrm{Aa}}$ & $7.00^{\mathrm{Ab}}$ & $6.00^{\mathrm{Ac}}$ \\
\hline \multirow{7}{*}{ 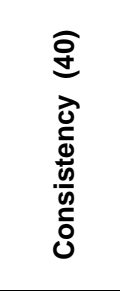 } & C & $31.00^{\mathrm{Ba}}$ & $30.00^{\mathrm{Bb}}$ & $23.00^{\mathrm{Bc}}$ \\
\hline & T1 & $34.00^{\mathrm{Aa}}$ & $33.50^{\mathrm{Ab}}$ & $26.00^{\mathrm{Ac}}$ \\
\hline & T2 & $35.00^{\mathrm{Aa}}$ & $33.00^{\mathrm{Ab}}$ & $26.00^{\mathrm{Ac}}$ \\
\hline & T3 & $35.00^{\mathrm{Aa}}$ & $32.50^{\mathrm{Ab}}$ & $26.00^{A C}$ \\
\hline & T4 & $35.00^{\mathrm{Aa}}$ & $33.00^{\mathrm{Ab}}$ & $26.00^{\mathrm{Ac}}$ \\
\hline & T5 & $36.00^{\mathrm{Aa}}$ & $34.00^{\mathrm{Ab}}$ & $27.00^{\mathrm{Ac}}$ \\
\hline & T6 & $35.00^{\mathrm{Aa}}$ & $33.00^{\mathrm{Ab}}$ & $26.00^{\mathrm{Ac}}$ \\
\hline \multirow{7}{*}{ 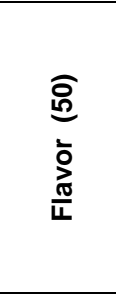 } & C & $47.00^{\mathrm{Aa}}$ & $45.00^{\mathrm{Ab}}$ & $37.00^{\mathrm{Ac}}$ \\
\hline & T1 & $47.00^{\mathrm{Aa}}$ & $45.00^{\mathrm{Ab}}$ & $38.00^{\mathrm{Ac}}$ \\
\hline & T2 & $46.00^{\mathrm{Aa}}$ & $45.00^{\mathrm{Ab}}$ & $37.00^{\mathrm{Ac}}$ \\
\hline & T3 & $47.00^{\mathrm{Aa}}$ & $45.00^{\mathrm{Ab}}$ & $38.00^{\mathrm{Ac}}$ \\
\hline & T4 & $46.00^{\mathrm{Aa}}$ & $44.00^{\mathrm{Ab}}$ & $37.00^{\mathrm{Ac}}$ \\
\hline & T5 & $48.00^{\mathrm{Aa}}$ & $45.00^{A b}$ & $38.00^{\mathrm{AC}}$ \\
\hline & T6 & $46.00^{\mathrm{Aa}}$ & $44.00^{\mathrm{Ab}}$ & $37.00^{\mathrm{Ac}}$ \\
\hline \multirow{7}{*}{$\begin{array}{l}\frac{8}{8} \\
\frac{\pi}{0} \\
\stackrel{0}{0}\end{array}$} & C & $85.00^{\mathrm{Ca}}$ & $81.25^{\mathrm{Cb}}$ & $65.50^{\mathrm{Cc}}$ \\
\hline & T1 & $89.15^{\mathrm{Ba}}$ & $85.00^{\mathrm{Bb}}$ & $70.00^{\mathrm{Bc}}$ \\
\hline & T2 & $89.25^{\mathrm{Ba}}$ & $85.00^{\mathrm{Bb}}$ & $69.50^{\mathrm{Bc}}$ \\
\hline & T3 & $90.00^{\mathrm{Ba}}$ & $85.00^{\mathrm{Bb}}$ & $70.50^{\mathrm{Bc}}$ \\
\hline & T4 & $89.75^{\mathrm{Ba}}$ & $84.50^{\mathrm{Bb}}$ & $69.50^{\mathrm{Bc}}$ \\
\hline & T5 & $92.00^{\mathrm{Aa}}$ & $86.50^{\mathrm{Ab}}$ & $71.00^{\mathrm{Ac}}$ \\
\hline & T6 & $89.00^{\mathrm{Ba}}$ & $84.00^{\mathrm{Bb}}$ & $69.00^{\mathrm{Bc}}$ \\
\hline
\end{tabular}

see legend to Table (2) for details

\section{CONCLUSION}

From such study, it could be reported that, high methoxy pectin (HMP) and guar gum (GG) as stabilizer at different ratios $(0.2$ and $0.4 \%)$ can be used without any affect on chemical composition and microbiological quality of drinking yoghurt throughout cold storage period. Addition of different stabilizers during drinking yoghurt prepration could be prevent serum separation with good viscosity caerrcter. Addition of $0.2 \%$ different stabilizer (HMP or GG) during drinking yoghurt making had no significant effect on the sensory quality of final product, while using $0.4 \%$ from different stabilizers caused a significant decrease in sensory porperties score of made drinking yoghurt compared with the control. The best treatment was that drinking yoghurt containing $50 \%$ yoghurt, $8 \%$ sugar and $42 \%$ water and fortified with $0.2 \%$ mix stabilizers $(0.1 \%$ guar gum + $0.1 \%$ High Methoxy Pectin), according to the sensory evaluation score

\section{REFERENCES}

Abd EL-Salam, M.H., El-Etriby, H.M. and Shahein, N.M. 1996. Influence of some stabilizers on some chemical and physical properties of yoghurt. Egypt. J. Dairy Sci., 24, 25-36.

American Public Health Association, 1994. Standard Method of the Examination of Dairy products $16^{\text {th }}$ Ed., Washington, USA.

AOAC, 2012. Official Methods of Analysis. $18^{\text {th }}$ ed. AOAC International Gaithersburg MD. No. (9685-080), and CH.4, pp. 56-57 and no. (985.01) Ch.3, p.6.

Azarikia, F. and Abbasi, S. 2010. On the stabilization mechanism of Doogh (Iranian yoghurt drink) by gum tragacanth. Food Hydrocolloids 24, 358-363.

Basiri, S., Haidary, N., Shekarforoush, S.S. and Niakousari, N. 2018. Flaxseed mucilage: A natural stabilizer in stirred yogurt. Carbohydrate Polymers 187, 59-65.

Chandan and Kilara, 2013. Manufacturing yogurt and fermented milks. (2 ${ }^{\text {nd }}$ Ed.). Hoboken: Wiley-Blackwell. New York, USA, pp. 297-318

De man, J.D., Rogosa, M. and Sharpe, M. 1960. A medium for the cultivation of lactabacilli. J. Appl. Bacterial., 23, 130-135.

Doleyres, Y., Schaub, L. and Lacroix, C. 2005. Comparison of the functionality of exopolysaccharides produced in situ or added as bioingredients on yogurt properties. J. Dairy Sci., 88, 4146-4156.

Ebrahimi, A., Sani, A.M. and Islami, M.H. 2015. Evaluation of Rheological, Physicochemical, and Sensory properties of Gundelia tournefortii yogurt. Bull. Env. Pharmacol. Life Sci., 4(11), 146-159.

EL-Batawy, O.I. 2012. Production and Properties of Low-fat set Yoghurt Made with Jerusalem Artichoke Powder. Egypt. J. Food Sci., 40, 7790.

El-Nagar, G.F. and Shenana, M.E. 1998. Production of acceptability of bio-yoghurt. PROC. $7^{\text {TH }}$ Egypt Conf. Dairy Sci. and Technol., pp. 227-240. 
Farahat, A.M. and El-Batawy, O.L. 2013. Proteolytic activity and some properties of stirred fruit yoghurt made using some fruits containing proteolytic enzymes. J. of Dairy Food Sci., 8(1), 38-44.

Fiszman, S.M., Lluch, M.A. and Salvador, A. 1999. Effect of addition of gelatin on microstructure of acidic milk gels and yoghurt and on their rheological properties. Int. Dairy J. 9, 895-901.

Foley, J., and Mulcahy, A.J., 1989. Hydrocolloid stabilization and heat treatment for prolonging shelf life of drinking yoghurt and cultured buttermilk. Irish J. of Food Science and Technology, 13(1), 43-50.

Gharibzahedi, S.M.T., Chronakis, I.S., 2018. Crosslinking of milk proteins by microbial transglutaminase: utilization in functional yogurt products. Food Chem., 245, 620-632.

Gould, G.R., 1991. In: Goldberg, I. and Williams R. (Ed). Biotechnology and Food Ingredients. Van Nostrand Reinhold, New York, USA, 461p.

Guven, M., 1998. Effects of stabilizer usage on some quality characteristics of yoghurt. Gida, 23(2), 133-139.

Hansen, P.M.T. 1993. Food hydrocolloids in the dairy industry. In K. Nishinari. and Doi E. (Eds.). Food hydrocolloids: structures, properties and functions. New York, USA. Plenum press, pp. 211-224.

Harrigan, W.F. and McCance, M.E. 1966. Laboratory Methods in Food and Dairy Microbiology. ( $8^{\text {th }}$ Ed.). New York, USA, pp. 292-293.

Harwalker, V.R. and Kalab, M., 1986. Relationship between microstructure and susceptibility to syneresis in yoghurt made from reconstituted nonfat dry milk. Food Microstructure, 5, 287293.

Hematyar, N., Samarin, A.M., Poorazarang, H. and Elhamirad, A.H., 2012. Effect of Gums on Yoghurt Characteristics. World Applied Sci. J. 20 (5), 661-665.

Ibarz, A. and Barbosa-Canovas G.V., 2002. Unit Operations in Food Engineering, CRC press, New York, USA. Chapter 6, 89-117.

Ibrahim, N.H., Bin, C.M.Y., Ping, T.C. and Idris, N.A., 2009. Droplet characterization and stability of soybean oil/palm kernel olein O/W emulsions with the presence of selected polysaccharides. Food Hydrocolloids. 23, 233-243.

Ibrahim, G.A., Mahna Nayra, Sh. and Diaa, A.G., 2004. Preparation and properties of set fermented milk containing inulin and different probiotics. Proc. The $9^{\text {th }}$ Egypt. Conf. for Dairy
Sci. Technol., "Milk and Dairy Products for a Health Future", pp. 117-132.

Joudaki, H., Mousavi, M., Safari, M., Razavi S.H., Emam-Djomeh, Z. and Gharibzahedi, S.M.T. 2013. Scrutinizing the different pectin types on stability of an Iranian traditional drink (Doogh). International J. of Biological Macromolecules $60,375-382$.

Keating, K. and Randwhite C.H. 1990. Effect of alternative sweeteners in plain and fruit flavoured yoghurt. J. Dairy Sci., 37, 54-59.

Kebary, K.M.K., Hussein, S.A. and Badawi, R.M. 2004. Impact of fortification of cow's milk with a modified starch on yoghurt quality. Egypt. J. Dairy Sci., 32, 111-124.

Koksoy, A. and Kilic, M., 2004. Use of hydrocolloids in textural stabilization of a yoghurt drink, ayran. Food Hydrocolloids, 18, 593-600.

Koksoy, A. and Kiliç, M. 2003. Effect of water and salt level on rheological properties of Aryan, a Turkish yoghurt. International Dairy J., 13(10), 835-839.

Lam, M., Shen, R., Paulsen, P. and Corredig, M. 2007. Pectin stabilization of soy protein isolates at low $\mathrm{pH}$. Food Research International, 40, 101-110.

Ling, E.F., 1963. A Text Book of Dairy Chemistry. Vol. 2, Practical, $3^{\text {rd }}$ Ed., Chapman and Hall Ltd., London, pp. 76-98.

Long, Z., Zhao, Q., Liu, T., Kuang, W., Xu, J. and Zhao, M. 2012. Role and properties of guar gum in sodium caseinate solution and sodium caseinate stabilized emulsion. Food Research International 49, 545-552.

Lucey, J., Tamehana, M., Singh, H., and Munro, P. 1999. Stability of model acid milk beverage: Effect of pectin concentration, storage temperature and milk heat treatment. J. of Texture Studies, 30, 305-318.

Mehanna, N. Sh., Ibrahim, G.A. and Gad El-Rab, D.A., 2003. The influence of inulin addition on the quality of functional fermented milk. Minufiya J. Agric. Res. 28, 887-907.

Nikoofar, E., Hojjatoleslami, M. and Shariaty, M.A. 2013. Surveying the effect of quince seed mucilage as a fat replacer on texture and physicochemical properties of semi fat set yoghurt. Int. J. Farm Alli. Sci., 2, 861-865.

Oliveira, R.P., Perego, P., Converti, A. and Oliveira, M.N. 2009. Effect of inuli on growth and acidification performance probiotic in cocultures and mixed culture with Streptococcus thermophilus. J. Food Engineering, 91, 133139. 
Oliviera, M.N., Sodini, I., Remeuf, E., Tissier, J.P., and Corrieu, G. 2002. Manufacture of fermented lactic beverages containing probiotic cultures. J. of Food Science, 67(6), 23362341.

Panahi, S., Fernandez, M.A., Marette, A. and Tremblay, A., 2017. Yogurt, diet quality and lifestyle factors. Eur. J. Clin. Nutr., 71, 573579.

Pathania, D., Gupta, D., Kothiyal, N.C., Sharma, G., Eldesoky, G.E. and Naushad, M. 2016. Preparation of a novel chitosan-g-poly (acrylamide)/ Zn nanocomposite hydrogel and its applications for controlled drug delivery of ofloxacin. International J. of Biological Macromolecules, 84, 340-348.

Penna, A.L.B., Sivieri, K. and Oliviera, M.N., 2001. Relation between quality and rheological properties of lactic beverages. J. of Food Engineering, 49(1), 7-13.

Pereira, P.C. 2014. Milk nutritional composition and its role in human health. Nutrition 30, 619627.
Pohjanheimo, T. and Sandell, M. 2009. Explaining the liking for drinking yoghurt: the role of sensory quality, food choice motives, health concern and product information. Inter. Dairy J., 19(8), 459-466.

Pseephol, T. and Sherkat, F. 2009. Probiotic stability of yoghurt containing Jerusalem artichoke inulins during refrigerated storage. J. Functional Foods, 1, 311-318.

SAS, 2006. Statistical Analysis System, SAS User's Guide: Statistics. SAS Institute Inc. Editors, Cary, NC.

Terzaghi, B.E. and Sandine, W.E. 1975. Improve medium for lactic streptococci and their bacteriophages. Appl. Microbiol., 29, 807-813.

Thombare, N., Jha, U., Mishra, S. and Siddiqui, M.Z. 2016. Guar gum as a promising starting material for diverse applications: A review. Int. J. of Biol. Macromolecules, 88, 361-372.

Walter, T. 1993. New application specific fat replacers for the dairy industry. Int. Food Ingredient 4, 29-32. 



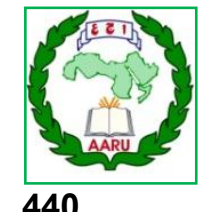

المؤتمر الرابع عثر لبحوث التنمية الزراعية،

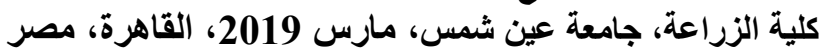

مجلا(27)، عدد (1)، عدد خاص مارس، مارس 2019 (19)-431

Website: http://strategy-plan.asu.edu.eg/AUJASCI/

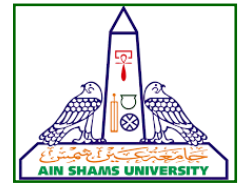

خواص مشرويات الزيادي المصنعة باستخدام أنواع مختثفة من المثبتات

[40]

أحمد ثروت صبحي- رزق عزب عواد - زكريا محمد رزق حسن - أسامة ابراهيم البطاوي

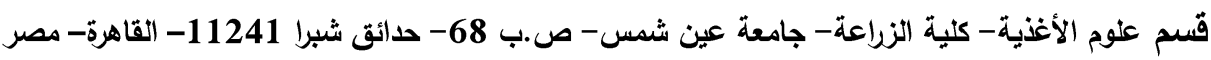

*Corresponding author: Ahmedsarwat14@yahoo.com

Received 20 February, 2019, $\quad$ Accepted 9 March, 2019

الزبادي (المقارنة والمعاملات) على المستويات

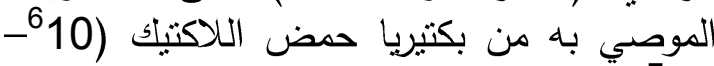

10 وحدة مكونة للمستعمر / جرام) وذللك في نهاية المناية

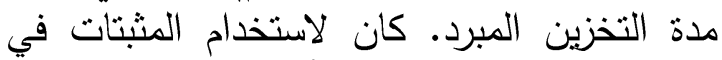

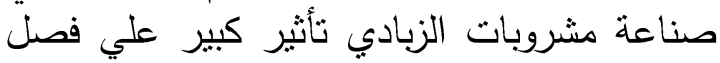

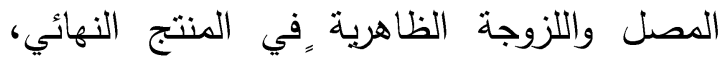
وكان التأثير الاكثر وضوحا عند استخدام خليط مثنتات (0.1\% بكتين+0.1\% صدخ الجوار ) عن

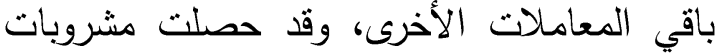

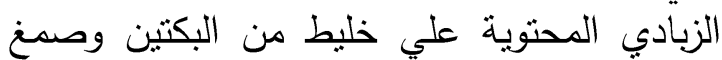
الجوار (1:1) والمضافة بنسبة 0.2\% على بلى أعلى

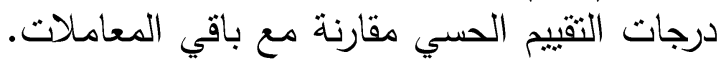
يمكن التوصية بتدعيم مشروبات الزبادي المئي المحتوية

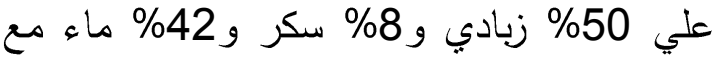

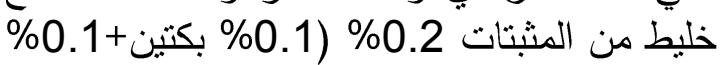

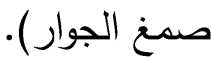

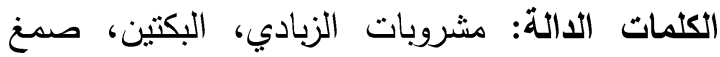
الجوار ، الخواص الريولوجية، الخواص الحسية الزية النين،

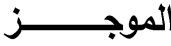

تم تحضير مشروبات زبادي مختلفة باستخدام أنواع وتركيزات مختلفة من المثبتات. ونت تحضير

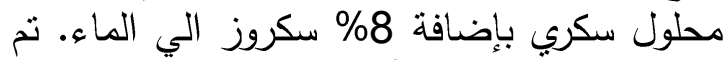

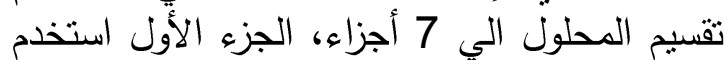

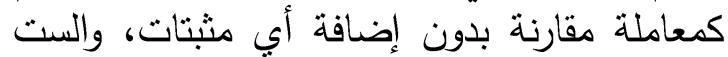
أجزء الأخرى تم فيها إضافة نوعين من الجنافي المثبات

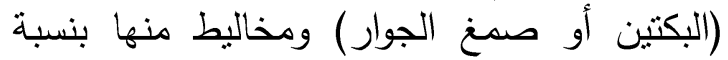

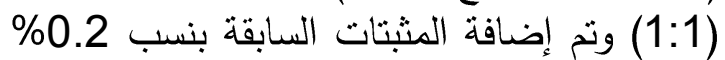

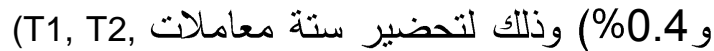

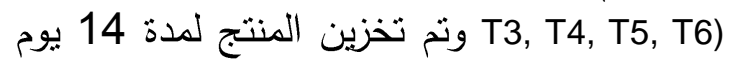

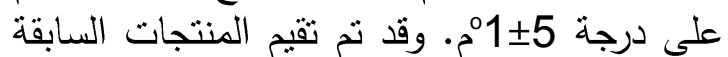

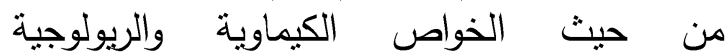
والميكروبيولوجية وكذلك الجودة الحسية في المنتج

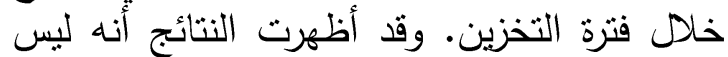

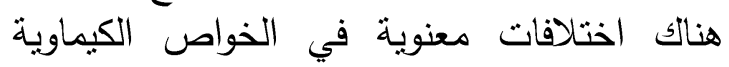

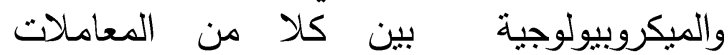

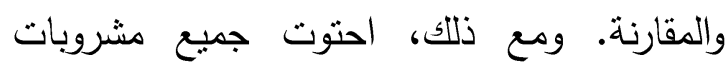

تحكيم: ا.د يوسف مرسي الكناني

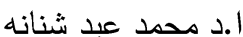

